\title{
Formation of Bulk Glassy Ni-(Co-)Nb-Ti-Zr Alloys with High Corrosion Resistance
}

\author{
Shujie Pang, Tao Zhang, Katsuhiko Asami and Akihisa Inoue \\ Institute for Materials Research, Tohoku University, Sendai 980-8577, Japan
}

\begin{abstract}
$\mathrm{Ni}_{60-x} \mathrm{Co}_{x} \mathrm{Nb}_{20} \mathrm{Ti}_{10} \mathrm{Zr}_{10}(x=0-40$ at $\%)$ glassy alloys were formed by melt spinning and a large supercooled region of over $40 \mathrm{~K}$ for the $0-20$ at\% Co alloys was found. The $\mathrm{Ni}_{60-} \mathrm{Co}_{x} \mathrm{Nb}_{20} \mathrm{Ti}_{10} \mathrm{Zr}_{10}(x=0-20$ at\%) alloys have high glass-forming ability leading to the formation of bulk glassy rods with diameters up to $1.5 \mathrm{~mm}$ by copper-mold casting. The bulk glassy alloys with $0-20$ at\% Co exhibited nearly the same anodic polarization behavior in $1 \mathrm{~N} \mathrm{HCl}$ solution. They were spontaneously passivated with a low passive current density of the order of $10^{-2} \mathrm{~A} / \mathrm{m}^{2}$ and no pitting corrosion due to anodic polarization with a potential sweeping up to $2.0 \mathrm{~V} \mathrm{vs}$. $\mathrm{Ag} / \mathrm{AgCl}$ occurred, indicating their high corrosion resistance in the aggressive acid.
\end{abstract}

(Received April 17, 2002; Accepted May 20, 2002)

Keywords: bulk glassy alloy, nickel-based alloy, supercooled liquid region, corrosion

\section{Introduction}

Since the syntheses of $\left.\mathrm{Ln}^{-1}{ }^{1}\right)(\mathrm{Ln}=$ lanthanide metals $)$, $\mathrm{Mg}^{-2)}$ and Zr-based ${ }^{3-5)}$ bulk glassy alloys, a number of bulk glassy alloys have been developed in multi-component systems during the last decade. ${ }^{6-8)}$ Especially the $\mathrm{Zr}-$ and $\mathrm{Pd}-\mathrm{Cu}-$ based bulk glassy alloys have been used as practical materials of sporting goods and electrodes. ${ }^{6-8)}$ Considering applications as engineering materials, development of bulk glassy $\mathrm{Ni}-$ based alloys is of great importance and high chemical stability in severe environment can be expected for Ni-based glassy alloys. Although a number of Ni-based amorphous alloys have been prepared by melt spinning, the formation of bulk glassy Ni-based alloys was reported only in recent years, as exemplified for Ni-Nb-Cr-Mo-P-B, ${ }^{9)} \mathrm{Ni}-\mathrm{Co}-\mathrm{Fe}-\mathrm{Cr}-\mathrm{Mo}-\mathrm{Nb}-$ $\mathrm{P}-\mathrm{B},{ }^{10)} \mathrm{Ni}-\mathrm{Cr}-(\mathrm{Mo}, \mathrm{Ta})-\mathrm{P}-\mathrm{B},{ }^{11)} \mathrm{Ni}-\mathrm{Nb}-\mathrm{Ta}-\mathrm{P}^{12)}$ and $\mathrm{Ni}-\mathrm{Cr}-$ Ta-Mo-P-B ${ }^{13)}$ systems, which exhibited high corrosion resistance in corrosive acids. However, the addition of $\mathrm{P}$ is disadvantageous because of its high vapor pressure during preparation of master alloys. Subsequently, formation of bulk glassy alloys in $\mathrm{Ni}-\mathrm{Ti}-\mathrm{Zr}-(\mathrm{Si}, \mathrm{Sn})$ system has been reported, but there are no data on their chemical properties. ${ }^{14)}$ Furthermore, it is known that the existence of metalloid elements in their alloys is detrimental for mechanical properties, such as ductility.

Recently, new Ni-based bulk glassy alloys free from metalloids with high strength and good ductility have been synthesized for the first time in $\mathrm{Ni}-\mathrm{Nb}-\mathrm{Ti}-\mathrm{Zr}$ base system by meltclap or copper-mold casting method. ${ }^{15)}$ It is well known that valve metals, such as $\mathrm{Nb}, \mathrm{Ti}$ and $\mathrm{Zr}$, are corrosion-resistant elements in aggressive acids with low oxidizing ability. It is also considered that $\mathrm{Co}$ and $\mathrm{Ni}$ are ferrous group elements locating next to each other in the periodic table and their atomic sizes are same. ${ }^{16)}$ Therefore, we have systematically explored $\mathrm{Ni}_{60-x} \mathrm{Co}_{x} \mathrm{Nb}_{20} \mathrm{Ti}_{10} \mathrm{Zr}_{10}$ system alloys with regards to the effects of substituting $\mathrm{Ni}$ with $\mathrm{Co}$ on the glass-forming ability and corrosion behavior. This paper presents the composition range in which glassy alloys with a large supercooled liquid region before crystallization are formed in the $\mathrm{Ni}-(\mathrm{Co}-) \mathrm{Nb}-$ $\mathrm{Ti}-\mathrm{Zr}$ system. The formation, thermal properties and corro- sion behavior of their bulk glassy alloys are investigated.

\section{Experimental Procedure}

Alloy ingots with nominal compositions of $\mathrm{Ni}_{60-x} \mathrm{Co}_{x}-$ $\mathrm{Nb}_{20} \mathrm{Ti}_{10} \mathrm{Zr}_{10}(x=0,5,10,15,20,30,40$ and 50 at\%) were prepared by arc melting mixtures of the pure metals in an argon atmosphere. From the master alloys, ribbon samples with a cross section of $0.02 \times 1 \mathrm{~mm}^{2}$ were fabricated by melt spinning. Bulk alloys in a rod form with a length of about $40 \mathrm{~mm}$ and diameters up to $2 \mathrm{~mm}$ were prepared by coppermold casting. The structure of the specimens was examined by $\mathrm{X}$-ray diffraction (XRD) using $\mathrm{Cu}-\mathrm{K} \alpha$ radiation. The thermal stability associated with glass transition, supercooled liquid and crystallization for the glassy alloys was investigated by differential scanning calorimetry (DSC) at a heating rate of $0.67 \mathrm{~K} / \mathrm{s}$. Corrosion behavior of the bulk glassy alloys was evaluated by potentiodynamic polarization with a potential sweep rate of $50 \mathrm{mV} / \mathrm{min}$ in $1 \mathrm{~N} \mathrm{HCl}$ solution. Prior to the electrochemical measurements, the specimens were mechanically polished in cyclohexane with silicon carbide paper up to No. 1500, degreased in acetone, washed in distilled water, dried in air and further exposed to air for $24 \mathrm{~h}$ for good reproducibility. The measurements were conducted in a three-electrode cell using a platinum counter electrode and a $\mathrm{Ag} / \mathrm{AgCl}$ reference electrode.

\section{Results and Discussion}

For melt-spun $\mathrm{Ni}_{60-x} \mathrm{Co}_{x} \mathrm{Nb}_{20} \mathrm{Ti}_{10} \mathrm{Zr}_{10}(x=0,5,10,15$, 20,30 and 40 at\%) alloys, there was a main halo peak at diffraction angles $(2 \theta)$ of around 42 degrees in their XRD patterns and no diffraction peak corresponding to a crystalline state was seen. However, the XRD pattern of the alloy containing 50 at $\%$ Co exhibited crystalline peaks. It is indicated that the $\mathrm{Ni}_{60-x} \mathrm{Co}_{x} \mathrm{Nb}_{20} \mathrm{Ti}_{10} \mathrm{Zr}_{10}$ alloys containing 0 40 at $\%$ Co can be formed in a glassy single-phase state without crystallinity by melt spinning.

Figure 1 shows the DSC curves of the melt-spun $\mathrm{Ni}_{60-x} \mathrm{Co}_{x} \mathrm{Nb}_{20} \mathrm{Ti}_{10} \mathrm{Zr}_{10}(x=0,5,10,15,20,30$ and 40 at $\%)$ 


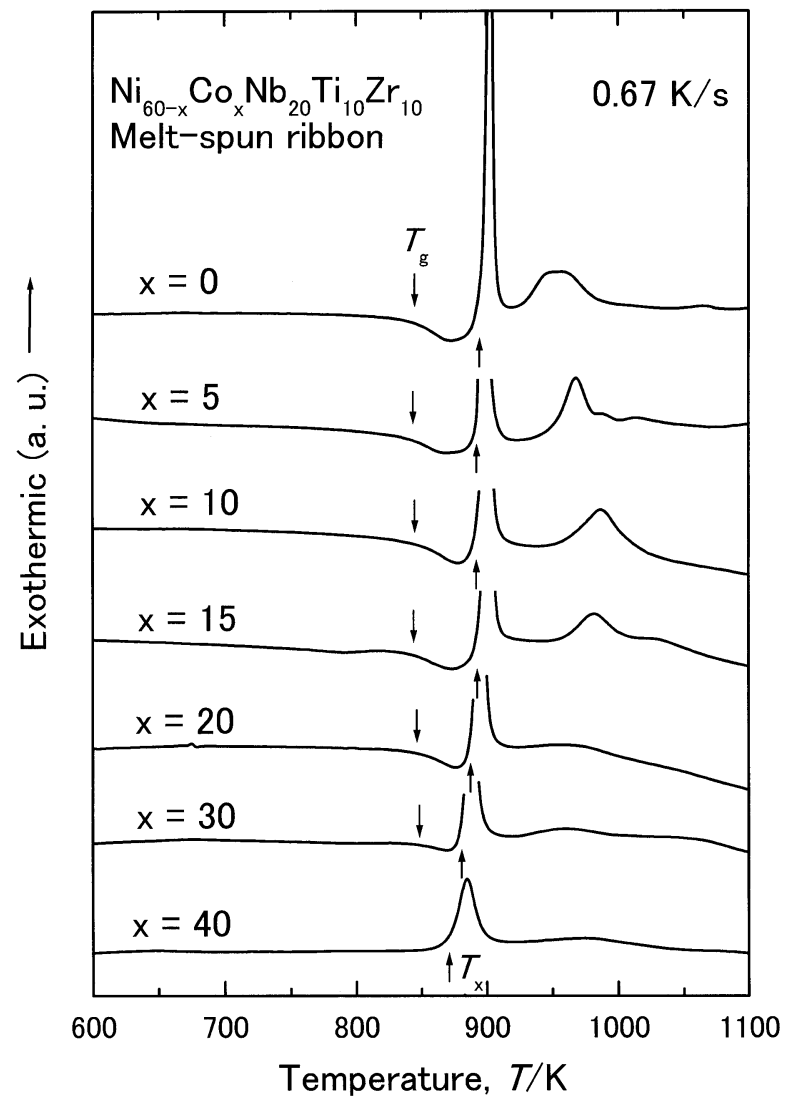

Fig. 1 DSC curves of melt-spun $\mathrm{Ni}_{60-x} \mathrm{Co}_{x} \mathrm{Nb}_{20} \mathrm{Ti}_{10} \mathrm{Zr}_{10}(x=0,5,10$, $15,20,30$ and 40 at $\%$ ) alloys.

alloys, where $T_{\mathrm{g}}$ and $T_{\mathrm{x}}$ correspond to glass transition temperature and onset temperature of crystallization, respectively. The distinct glass transition, followed by a supercooled liquid region prior to crystallization is recognized for the alloys containing 0-30 at\% Co, though no glass transition is seen for the 40 at $\%$ Co alloy. A large temperature interval of supercooled liquid region $\left(\Delta T_{\mathrm{x}}\right)$ of about $50 \mathrm{~K}$, defined by the difference between $T_{\mathrm{x}}$ and $T_{\mathrm{g}}\left(\Delta T_{\mathrm{x}}=T_{\mathrm{x}}-T_{\mathrm{g}}\right)$, is recognized for the glassy $\mathrm{Ni}_{60-x} \mathrm{Co}_{x} \mathrm{Nb}_{20} \mathrm{Ti}_{10} \mathrm{Zr}_{10}(x=0,5,10$ and 15 at\%) alloys, indicating a high thermal stability of the supercooled liquid. For the alloys containing 20 and 30 at $\% \mathrm{Co}$, the $\Delta T_{\mathrm{x}}$ decreases to $40 \mathrm{~K}$ and $32 \mathrm{~K}$, respectively, due to a slight increase in $T_{\mathrm{g}}$ and a distinct decrease in $T_{\mathrm{x}}$.

Furthermore, bulk alloys with diameters of $1-1.5 \mathrm{~mm}$ consisting of a glassy single phase were formed in the composition range of $0-20$ at\% Co for the $\mathrm{Ni}_{60-x} \mathrm{Co}_{x} \mathrm{Nb}_{20} \mathrm{Ti}_{10} \mathrm{Zr}_{10}$ alloys. Their outer surfaces were smooth and no concave due to the precipitation of a crystalline phase was seen. Figure 2 shows the X-ray diffraction patterns of the bulk glassy alloys with their maximum diameters for glass formation. It is seen that the maximum diameter for glass formation is $1 \mathrm{~mm}$ for the 0,15 and 20 at $\%$ Co alloy. With the addition of 5 and 10 at $\%$ Co for replacing $\mathrm{Ni}$, the glass-forming ability of the alloys is increased as evidenced from the formation of bulk glassy rods with a diameter up to $1.5 \mathrm{~mm}$. The glassy single-phase nature of the bulk samples was further confirmed by comparing their DSC curves with those of the melt-spun ribbons. Figure 3 shows the DSC curves of the glassy $\mathrm{Ni}_{55} \mathrm{Co}_{5} \mathrm{Nb}_{20} \mathrm{Ti}_{10} \mathrm{Zr}_{10}$ melt-spun ribbon and cast rods

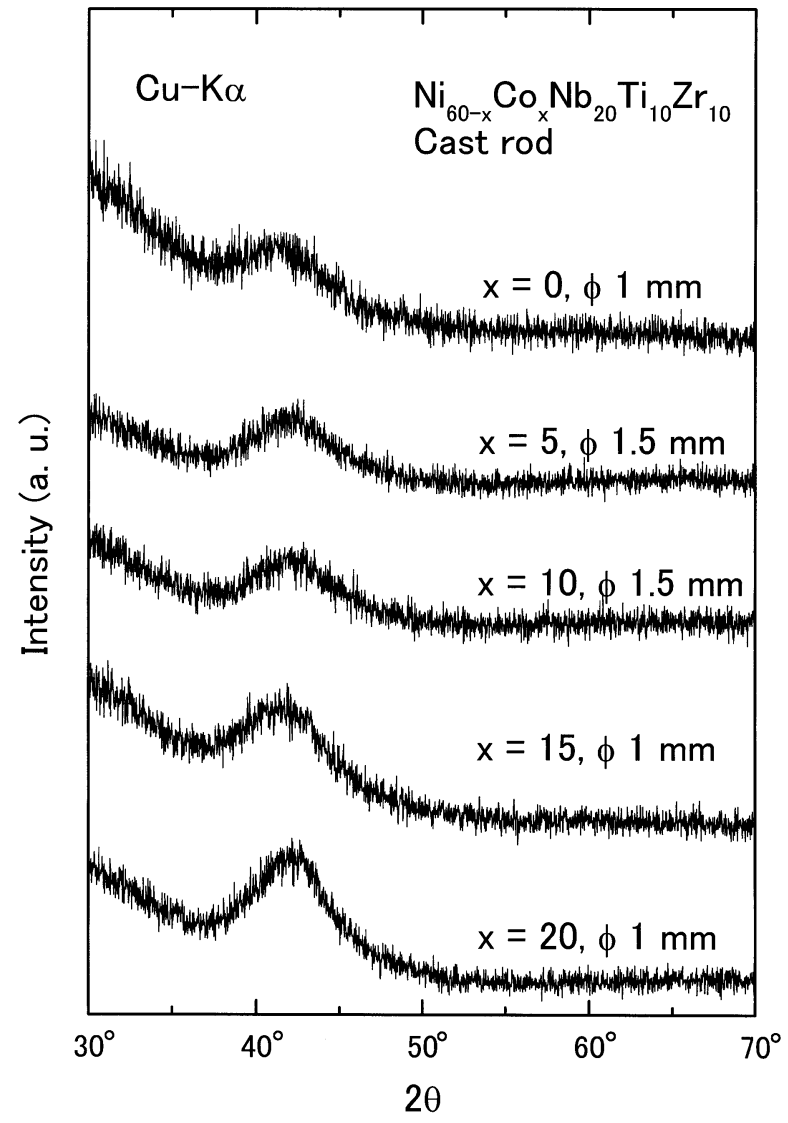

Fig. 2 X-ray diffraction patterns of bulk glassy $\mathrm{Ni}_{60-x} \mathrm{Co}_{x} \mathrm{Nb}_{20} \mathrm{Ti}_{10} \mathrm{Zr}_{10}$ $(x=0,5,10,15$, and 20 at $\%)$ alloys with their maximum diameters for glass formation.

with diameters of $1 \mathrm{~mm}$ and $1.5 \mathrm{~mm}$. The heat of the main exothermic peaks is $3.9 \mathrm{~kJ} / \mathrm{mol}$ for the $1 \mathrm{~mm}$ rod, $4.2 \mathrm{~kJ} / \mathrm{mol}$ for the $1.5 \mathrm{~mm}$ rod and $4.0 \mathrm{~kJ} / \mathrm{mol}$ for the melt-spun ribbon. It is indicated that there is no distinct difference in the $T_{\mathrm{g}}, T_{\mathrm{x}}$ and heat of the crystallization reactions among the bulk and ribbon samples.

As described above, the glassy $\mathrm{Ni}_{60-x} \mathrm{Co}_{x} \mathrm{Nb}_{20} \mathrm{Ti}_{10} \mathrm{Zr}_{10}$ $(x=0-20$ at $\%)$ alloys exhibited a high thermal stability of supercooled liquid against crystallization $\left(\Delta T_{\mathrm{x}} \geq 40 \mathrm{~K}\right)$ and high glass-forming ability leading to the formation of the bulk glassy rods with diameters up to $1.5 \mathrm{~mm}$. By contrast, the melt-spun 30 at $\%$ Co alloy exhibited a small $\Delta T_{\mathrm{x}}$ value of $32 \mathrm{~K}$ and the 40 at\% Co ribbon showed no glass transition and no bulk glassy samples were obtained by using these two alloy compositions. It has been proposed that the alloys possessing high thermal stability of supercooled liquid against crystallization satisfy the three composition rules for the achievement of high glass-forming ability, ${ }^{6,7,17)}$ i.e., (1) multi-component system consisting of more than three elements, (2) significant difference in atomic size ratios above about $12 \%$ among the main constituent elements, and (3) suitable negative heats of mixing among their elements. The atomic size changes in the order of $\mathrm{Zr} \gg \mathrm{Nb}>\mathrm{Ti} \gg$ $\mathrm{Co}=\mathrm{Ni}^{16}$ ) and the heat of mixing is negative values of $25-49 \mathrm{~kJ} / \mathrm{mol}$ for the atomic pairs of $(\mathrm{Ni}, \mathrm{Co})-\mathrm{Nb},(\mathrm{Ni}, \mathrm{Co})$ $\mathrm{Ti}$ and $(\mathrm{Ni}, \mathrm{Co})-\mathrm{Zr}{ }^{18)}$ Thus, the data on the atomic size and the chemical bonding nature of the $\mathrm{Ni}-(\mathrm{Co}-) \mathrm{Nb}-\mathrm{Ti}-\mathrm{Zr}$ system indicate the satisfaction of the three composition rules, 


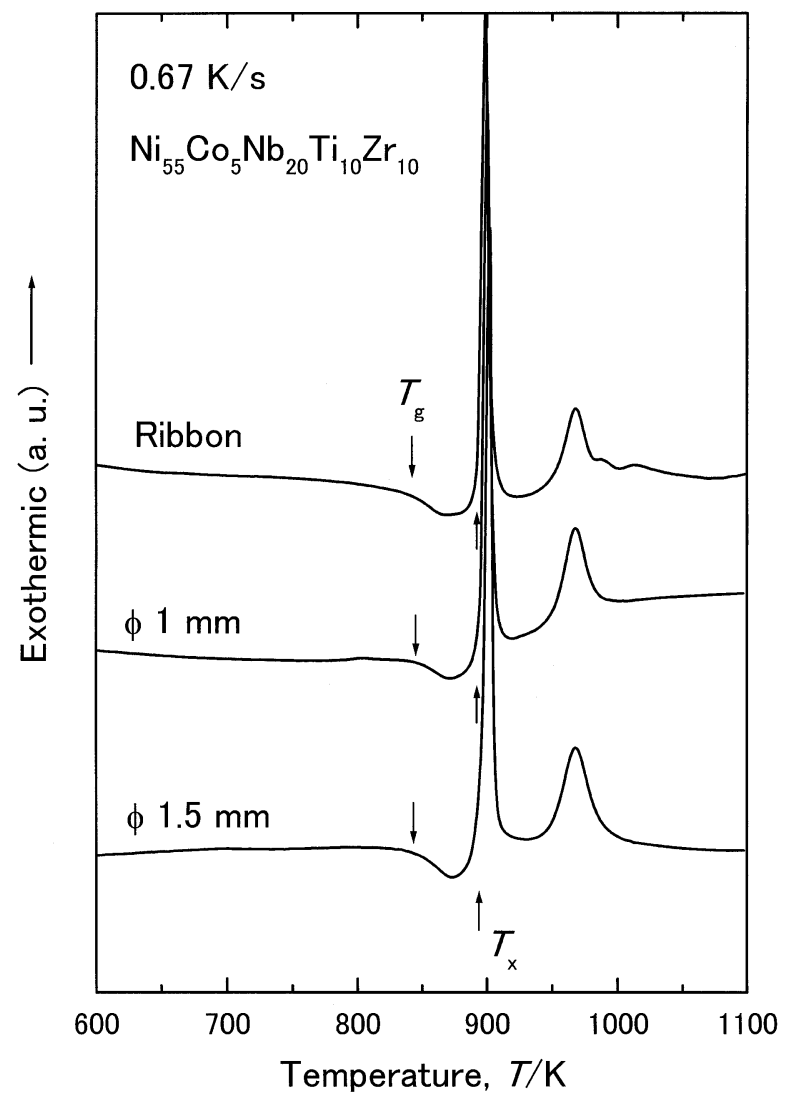

Fig. 3 DSC curves of the glassy $\mathrm{Ni}_{55} \mathrm{Co}_{5} \mathrm{Nb}_{20} \mathrm{Ti}_{10} \mathrm{Zr}_{10}$ melt-spun ribbon and cast rods with diameters of $1 \mathrm{~mm}$ and $1.5 \mathrm{~mm}$.

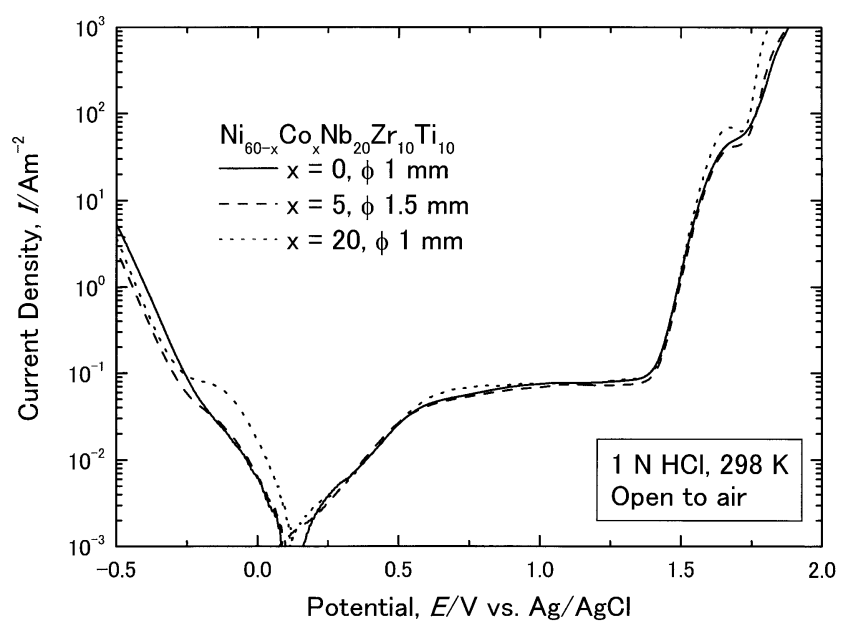

Fig. 4 Potentiodynamic polarization curves of the bulk glassy $\mathrm{Ni}_{60-x} \mathrm{Co}_{x}$ $\mathrm{Nb}_{20} \mathrm{Ti}_{10} \mathrm{Zr}_{10}$ alloys with their maximum diameters for glass formation in $1 \mathrm{~N} \mathrm{HCl}$ solution open to air at $298 \mathrm{~K}$.

leading to the formation of the bulk glasses with a large supercooled liquid region. The mechanism for the stabilization of supercooled liquid for the alloys satisfying the composition rules has been described in previous papers and reviews. ${ }^{6,7,17)}$

The bulk glassy $\mathrm{Ni}_{60-x} \mathrm{Co}_{x} \mathrm{Nb}_{20} \mathrm{Ti}_{10} \mathrm{Zr}_{10}$ alloys containing $0-20$ at\% Co exhibited nearly the same polarization behavior in $1 \mathrm{~N} \mathrm{HCl}$ solution. As examples, the anodic polarization curves of the bulk glassy alloys containing 0,5 and 20 at\% Co measured potentiodynamically are shown in Fig. 4. All the glassy alloys exhibit high open-circuit potential of above $0 \mathrm{~V}$ vs. $\mathrm{Ag} / \mathrm{AgCl}$. In the corrosive hydrochlo- ric acid, they are spontaneously passivated and showed a low passive current density of the order of $10^{-2} \mathrm{~A} / \mathrm{m}^{2}$ until the evolution of $\mathrm{O}_{2}$ and/or $\mathrm{Cl}_{2}$ gases starts at the potential of about $1.35 \mathrm{~V}$ vs. $\mathrm{Ag} / \mathrm{AgCl}$. No pitting due to the polarization with a potential up to $2.0 \mathrm{~V}$ vs. $\mathrm{Ag} / \mathrm{AgCl}$ occurred. These results indicate high corrosion resistance of the bulk glassy $\mathrm{Ni}_{60-x} \mathrm{Co}_{x} \mathrm{Nb}_{20} \mathrm{Ti}_{10} \mathrm{Zr}_{10}(x=0,5,10,15$ and 20 at\%) alloys in the aggressive $\mathrm{HCl}$ solution. The high corrosion resistance of the glassy $\mathrm{Ni}-(\mathrm{Co}-) \mathrm{Nb}-\mathrm{Ti}-\mathrm{Zr}$ alloys is primarily attributed to the formation of a single solid solution alloy exceeding the solubility of alloying elements in the equilibrium state and hence allowing selective alloying of strongly passivating elements, $\mathrm{Nb}$, Ti and $\mathrm{Zr}$, which ensure the formation of a uniform and highly protective passive film.

\section{Summary}

Formation of glassy alloys in $\mathrm{Ni}-\mathrm{Co}-\mathrm{Nb}-\mathrm{Ti}-\mathrm{Zr}$ system with high thermal stability and corrosion resistance is reported. A glassy single phase was formed for $\mathrm{Ni}_{60-x} \mathrm{Co}_{x} \mathrm{Nb}_{20} \mathrm{Ti}_{10} \mathrm{Zr}_{10}(x=0-40$ at $\%)$ alloys by melt spinning. The glassy alloys exhibited a large $\Delta T_{\mathrm{x}}$ of about $50 \mathrm{~K}$ in the composition range of $0-15$ at $\% \mathrm{Co}$ and $40 \mathrm{~K}$ at 20 at $\% \mathrm{Co}$. Bulk glassy alloys with a diameter up to $1.5 \mathrm{~mm}$ were synthesized by using the $0-20$ at $\%$ Co alloys with the large $\Delta T_{\mathrm{x}}$. There was no distinct difference in polarization behavior for the bulk glassy alloys containing $0-20$ at $\%$ Co in $1 \mathrm{~N} \mathrm{HCl} \mathrm{so-}$ lution. They were spontaneously passivated at a low current density of the order of $10^{-2} \mathrm{~A} / \mathrm{m}^{2}$ and no pitting corrosion due to anodic polarization with a potential sweeping up to $2.0 \mathrm{~V}$ vs. $\mathrm{Ag} / \mathrm{AgCl}$ occurred in $1 \mathrm{~N} \mathrm{HCl}$ solution.

\section{REFERENCES}

1) A. Inoue, T. Zhang and T. Masumoto: Mater. Trans., JIM 31 (1990) $425-428$.

2) A. Inoue, A. Kato, T. Zhang, S.G. Kim and T. Masumoto: Mater. Trans., JIM 32 (1991) 609-616.

3) T. Zhang, A. Inoue and T. Masumoto: Mater. Trans., JIM 32 (1991) 1005-1010.

4) A. Inoue and T. Zhang: Mater. Trans., JIM 36 (1995) 1184-1187.

5) A. Peker and W. L. Johnson: Appl. Phys. Lett. 63 (1993) 2342-2344.

6) A. Inoue: Acta Mater. 48 (2000) 279-306.

7) A. Inoue: Bulk Amorphous Alloys, (Trans Tech Publications, Zurich, 1989).

8) W. L. Johnson, C. T. Liu and A. Inoue: Bulk Amorphous Alloys, (MRS, Warrendale, 1999).

9) X. M. Wang, I. Yoshii, A. Inoue, Y. H. Kim and I. B. Kim: Mater. Trans., JIM 40 (1999) 1130-1136.

10) X. M. Wang, I. Yoshii and A. Inoue: Mater. Trans., JIM 41 (2000) 539542.

11) H. Habazaki, T. Sato, A. Kawashima, K. Asami and K. Hashimoto: Mater. Sci. Engng. A304 (2001) 696-700.

12) A. Kawashima, H. Habazaki and K. Hashimoto: Mater. Sci. Engng. A304 (2001) 753-757.

13) H. Katagiri, S. Meguro, M. Yamasaki, H. Habazaki, T. Sato, A. Kawashima, K. Asami and K. Hashimoto: Corros. Sci. 43 (2001) 183191.

14) S. Yi, T. G. Park and D. H. Kim: J. Mater. Res. 15 (2000) 2425-2430.

15) T. Zhang and A. Inoue: Mater. Trans. 43 (2002) 708-711.

16) Metals Databook, ed. by Japan Inst. Metals (Maruzen, Tokyo, 1993) p. 8 .

17) A. Inoue: Mater. Trans., JIM 36 (1995) 866-875.

18) F. R. de Boer, R. Boom, W. C. M. Mattens, A. R. Miedema and A. K. Niessen: Cohesion in Metals, (North-Holland, Amsterdam 1989) pp. 103-637. 